\begin{tabular}{lr}
\hline \hline Lectio Praecursoria \\
\hline
\end{tabular}

\section{Vuorovaikutus sairaalajohtoryhmien kokouksissa}

Tomi Laapotti

FT, yliopistonlehtori

Tampereen yliopisto

tomi.laapotti@jyu.fi

Lectio praecursoria viestinnän väitöskirjaksi tarkoitetun tutkimuksen Vuorovaikutus sairaalajohtoryhmien kokouksissa tarkastustilaisuudessa Jyväskylän yliopistossa 27.10.2018. Vastaväittäjänä toimi vanhempi yliopistonlehtori, dosentti Pekka Pälli (Aalto yliopisto) ja kustoksena yliopistonlehtori, FT Leena Mikkola (Jyväskylän yliopisto).

Kun ryhmä, tiimi tai organisaatio haluaa saada jotain aikaiseksi, on yleensä ensimmäinen aske tapaamisen järjestäminen. Jos organisaatioss ei tiedetä mitä tehdä, pidetään kokous. Kokouksia on kaikkialla: työelämässä, harrastuksissa taloyhtiöissä, järjestöissä ja muissa yhteisöissä. Viime vuosina kokousten märän ja niihin käytetyn ajan on todettu lisääntyvän. Kokousten merkittävyydestä osana olemassaoloamme kertoo esimerkiksi se, että on todettu, että mikäl ihminen ei osallistu, tai osallistuu vain vähän, minkäänlaisiin kokouksiin, kertoo se yhteiskunnasta syrjäytymisestä. Samalla kokoukset ovat statussymboli: mitä ylempi status työelämässä, sitä enemmän aikaa kuluu kokouksissa ja niiden valmistelussa. Voidaankin sanoa, että tämän päivän maailmassa kaikista vaikutusvaltaisimmat ihmiset johtavat kokouksia. Elämme siis kokousyhteiskunnassa, olemme kokouslaji. Kaiken tämän keskellä kokoukset ovat niin itsestään selvä osa yhteiskunnan rakenteita, että niitä ei juuri pysähdytä pohtimaan. Mitä kokoukset ja erilaiset enemmän tai vähemmän muodolliset tapaamiset oikeastaan ovat?

Kokous, tapaaminen, palaveri, paltsu, miitinki, meillä on useita sanoja kokoukselle. Sanaa kokous ei kuitenkaan ole olemassa kaikissa kielissä tai luonnonvaraisissa yhteisöissä. Se, mitä me kutsuisimme kokoukseksi, mielletään puhumiseksi. Tämä on yksi lähtökohta kokousten olemuksen pohtimiselle. Sanan puhuminen käyttäminen alleviivaa sitä, että kokouksiss on pohjimmiltaan kyse vuorovaikutuksesta. Kokoukset ovat vuorovaikutusta. Miksi sitten emme pärjää pelkällä sanalla puhuminen vaan tarvitsemme kokouksen käsitteen? Kokous on käsitteenä sääntö tietynlaiselle vuorovaikutukselle. Tämän säännön tyydyttävä, saati miellyttävä noudattaminen on osoittautunut haastavaksi: kokouksia käsittelevää opaskirjallisuutta on kirjoitettu lukematon määrä ja erinomaise hyviä ohjeita hyvän kokouksen järjestämiseksi on saatavilla. Tästä huolimatta kokoukse ovat usein se yhteinen vihollinen työpaikkojen kahvipöytäkeskusteluissa: kokouksia pidetään tehottomina, tylsinä tai turhina. Aivan kuin kokoukset vastustaisivat oppaiden niksejä. Mitä kokoukset oikeastaan ovat ja miksi ne vastustavat muutosta?

Vaikka kokoukset ovat keskeinen osa yhteiskunnallisia rakenteita, on kokouksiin keskittynyt tutkimus runsastunut vasta aivan viim vuosina. Kokouksista on kyllä kerätty tutkimusaineistoja, mutta kokousta itsessään, ta edes erityisenä kontekstina, on tutkittu vain vähän. Sen sijaan kokous on asemoitu ikään kuin säiliöksi, jonka sisällä tapahtuu esimerkiksi päätöksentekoa, ongelmanratkaisua ta ideointia. Väitöstutkimukseni olen toteuttanut kokoustutkimuksen lähtökohdista. Kokoustutkimus perustuu ajatukselle, että kokoukset ovat organisoitumisen keskeisin käytänne eli organisaatiot tarvitsevat kokouksia. Toisin sanoen, kokoukset tuottavat organisaatiota, ei päinvastoin. Kokouksissa organisaatio tulee näkyväks ja olemassa olevaksi ja yksilöt tulkitsevat paikkaansa tässä organisaatiossa. Kokoukset on siis nähty keskeisinä vuorovaikutustilanteina, mutta prosesseja, joissa tämä keskeisyys todentuu, on tarkasteltu tutkimuskirjallisuudessa rajallisesti.
Tutkimuksessani pyrin kuvaamaan kokousvuorovaikutusta ja ymmärtämään kokousten merkitystä sairaalaorganisaatiolle ja kokousosallistujille. Näin ollen pyrin lisäämään ymmärrystä siitä, mitä kokoukset oikeastaan ovat. Tarkastelen kokousvuorovaikutusta sairaalajohtoryhmissä. Sairaala on tutkimuksen kontekstina omanlaisensa: perinteisesti sairaaloita on pidetty hierarkkisina, erikoistumisalueisiin jakaantuneina organisaatioina. Sairaalaan kohdistunut ryhmätutkimus on keskittynyt ensisijaisesti hoitotyötä tekeviin, usein moniammatillisiin tiimeihin, eli niin sanottujen hallinnollisten ryhmien, joita tutkimani johtoryhmät ovat, tutkimus on ollut vähäistä. Näin on, vaikka hallinnollinen työ on oleellinen osa sairaalan arkea. Sairaalajohtoryhmät, kuten monet muutkin julkisorganisaatioiden johtoryhmät, ovat usein erilaisten yksiköiden johtamisen tueksi perustettuja ryhmiä, joilla ei välttämättä ole päätöksentekovaltaa tai päätöksentekovastuita. Valta ja vastuu ovat yksittäisellä johtajalla, ei johtoryhmällä. Tutkimani sairaalajohtoryhmäkokoukset olivat muodollisia siinä mielessä, että ne järjestettiin säännöllisesti, niissä oli ennalta tiedoksi saatettu asialista ja niiden järjestäminen perustui sairaalan hallintosääntöön. Kokouskäytänteiden osalta kokoukset eivät olleet kovin muodollisia, esimerkiksi puheenvuoroja pyydettiin puheenjohtajalta vain harvoin.

Viestintätieteiden näkökulmasta tutkimukseni sijoittuu ryhmä- organisaatioviestinnän tutkimusperinteisiin. Ryhmäviestinnän, ja erityisesti ryhmätutkimuksen laajemmin, tutkimuksista valtaosa toteutetaan koeasetelmissa, niin kutsutuissa laboratorioryhmissä. Nämä ovat usein opiskelijoista muodostettuja ryhmiä, joiden tehtävänä on useimmiten tehdä päätös, ratkaista ongelma tai tuottaa ideoita ennalta asetetuissa aikaraameissa. Nämä koeasetelmat eivät vastaa organisaatioiden todellisuutta, jossa ryhmät ovat osa koko organisaation toi- 
mintaa, asettuvat osaksi ajallista jatkumoa ja ryhmien jäsenillä on usein yhteistä historiaa $\mathrm{j}$ tulevaisuutta. Lisäksi organisaatioissa kohdatu ongelmat ja tehdyt päätökset ovat vain harvoin sellaisia, että ne voitaisiin tyydyttävästi käsitell yhden ryhmätapaamisen aikana. Koeasetelmille on paikkansa osana ryhmätutkimusta, mutta niiden tulosten sovellettavuusarvo esimerkiksi työelämään on hyvin rajallinen. Tämän vuok si ryhmätutkimuksessa on jo vuosikymmenten ajan peräänkuulutettu tutkimusaineistojen keräämistä todellisista työelämän ryhmistä. Oma tutkimukseni on osa tätä liikettä, jolla pyritään tuottamaan teoreettista ymmärrystä työelämän ryhmistä ja niiden suhteesta niitä ympäröivään organisaatioon.

Märittelen ryhmän vuorovaikutuksen prosessiksi, jossa jaetaan informaatiota ja joss luodaan ja jaetaan yhteisiä merkityksiä. Vuorovaikutus määrittyy näin konstruoivaksi prosessiksi eli vuorovaikutuksessa luodaan sosiaalista todellisuutta. Näin ollen myös organisaati määrittyy vuorovaikutuksessa konstruoiduks kokonaisuudeksi. Laadullisella tutkimusotteella toteutettu, monimenetelmäinen väitöstu kimukseni rakentuu neljästä osatutkimuksesta, jotka on toteutettu itsenäisinä, empiirisin tutkimusartikkeleina. Tutkimusprosessi eten aineistolähtöisesti ja jälkimmäisten artikkelei den tutkimustavoitteet perustuivat aiempie artikkeleiden löydöksiin. Tutkimuksen aineistona on kymmenen videotallennettua sairaala johtoryhmäkokousta, viisi vastuualuetasolta ja viisi toimialuetasolta. Lisäksi yhdessä osatutkimuksessa aineistona on seitsemän johtoryhmäjäsenen haastattelua.

Kaksi ensimmäistä artikkelia tarkastelivat vuorovaikutuksen rakenteita. Havaitsin, että kokoukset ovat korostetusti tiedonjakamiseen keskittyneitä, että jaetusta tiedosta keskustellaan melko vähän ja että ongelmia tuodaan keskusteluun, mutta niitä ei yleensä ratkaista. Lisäksi osoitin kokousvuorovaikutuksen mukailevan organisaatiorakenteita. Tämä ilmeni siten, että lähijohtaja- tai johtaja-asemassa olevat osallistuivat selkeästi henkilöstön edustajia enemmän. Lisäksi organisaation horisontaaliset rakenteet vastuualueiden välillä rajoittivat ryhmän vuorovaikutusta: suurin osa kokouskeskustelusta oli kahdenkeskistä puheenjohtajan ja yhden osallistujan välillä, muiden kuunnellessa. Toiseen artikkeliin myös haastattelin kokousosallistujia: osallistujat pitivät kokouksia hyvinä ja tärkeinä, mutta kokivat haastavana kuvata kokousten konkreettisia hyötyjä esimerkiksi johtamistyölle. Osallistujien mukaan kokousten merkittävin anti oli ison kuvan saaminen sairaalan toiminnasta. Mielenkiintoista oli myös se, että osallistujat kokivat, että kokouksissa keskusteltiin ryhmätasolla, vaikka havainnointiaineisto osoitti keskustelun olevan lähinnä kahdenvälistä.

Kaksi jälkimmäistä osatutkimusta keskittyivät merkitysten luomiseen. Kolmannessa artikkelissani tarkastelin ongelmapuhetta. Ongelmapuheen analyysi osoitti, että ongelmia nostettiin esiin kokouksen itsensä, tai kokouksen tehtävälistan vuoksi, esimerkiksi ajankohtaisista asioista kerrottaessa. Akuutitkaan ongelmat eivät välttämättä aiheuttaneet keskustelua eikä niitä pyritty ratkaisemaan. Toisaalta silloin kun ongelmista keskusteltiin ja luotiin yhteisiä merkityksiä, johtoryhmäkokousten asema osoittautui tärkeäksi osaksi organisaation ongelmanratkaisuprosesseja, vaikka ongelmien varsinainen ratkaisu tapahtuikin jossain muualla. Ongelmapuheen kautta luotiin myös johtoryhmän koheesiota ja yksimielisyyttä: esimerkiksi ilmaistiin jonkin asian olevan ongelmallinen tai organisaation linjauksen olevan ongelmallinen ja samalla todettiin, ettei ryhmä voi asialle mitään, jolloin ryhmä ikään kuin moraalisesti erotti itsensä organisaatiosta.
Koska johtoryhmien jäsenet olivat kertoneet kokousten merkityksellisyyden olevan ensisijaisesti ison kuvan muodostamisessa, tarkastelin neljännessä artikkelissani sairaalaorganisaation merkityksentämistä eli sitä, miten sairaalast puhuttiin kokouksissa. Sairaalasta puhuttiin joko yksipuolisesti tiedottamalla, jolloin äänessä oli ikään kuin sairaala itse tai ryhmän keskusteluissa, jolloin äänessä oli ryhmä. Sairaala merkityksennetään siis sekä sairaalan että kokousosallistujien näkökulmasta, ja kummankin osapuolen tavoitteita edistetään kokouksissa.

Tutkimukseni tulosten yhteenvetona totean seuraavaa: Johtoryhmäkokousten merkitys kokousosallistujille ja sairaalaorganisaatiolle on moninainen eikä rajoitu ainoastaan kokousten tehtävätavoitteisiin. Johtoryhmäkokousten keskeiset tehtävätavoitteet, toimia johtamisen tukena ja jakaa tietoa, toteutuvat ensisijaisest tiedottamistyyppisen tiedonjakamisen kautta. Tehtävätason prosessien ohella kokousten merkitys muodostuu suhdetasolla: sairaalan iso kuva muodostuu tiedottamisen, mutta myö yhteisten merkityksentämiskeskusteluiden kautta, jolloin luodaan ja ylläpidetään ryhmän koheesiota ja positioidaan ryhmää osaksi sairaalaa. Yksilötasolla saadaan tukea ja tunnetaan kuulumista sekä johtoryhmään että sairaalaan. Kokousten rooli on toimia muodollisena, legitimoituna foorumina, jossa organisaation olemassaolon prosessia merkityksennetään Johtoryhmäkokousten julkilausumaton tehtäva on siis toimia tilanteena, jossa sairaalaa ja sen toimintaa jäsennetään ymmärrettäväksi kokonaisuudeksi. Kokouksissa organisaatio esitellään sen jäsenille ja luodaan mielikuva organi saation toiminnasta rationaalisena ja loogisen ja samalla sitoutetaan jäsenet osaksi organisaatiota. Kokouksissa ilmenee samalla sosiaalisen ideaalin ja sosiaalisen todellisuuden välinen suhde, joka voi olla ristiriitainenkin. Se, mit kokouksessa sanotaan, on usein jo yksinker- taistus vallitsevasta asiaintilasta ja edelleen se, mitä lopulta kirjataan kokousmuistioon saattaa olla vahvasti kaunisteltu tai tahallisen epämääräinen ilmaus. Kokoukset siis tiivistävät ja jäsentävät organisaatiotodellisuutta. Mutta kenen ehdoilla?

Näiden tulosten pohjalta esitän johtopäätökseni ryhmätutkimuksen, sairaalajohtoryhmätutkimuksen ja kokoustutkimuksen näkökulmista.

Ryhmätutkimuksen kannalta tutkimukseni tulokset vahvistavat niin kutsuttujen luonnollisten ryhmien tutkimisen tärkeyttä. Johtoryhmät uppoutuvat osaksi organisaation ajallista jatkumoa ja osallistuvat organisatoristen ongelmien ratkaisuun, vaikka varsinainen ratkaisu tapahtuisikin toisaalla. Erityisesti tutkimukseni osoittaa kokouskontekstin merkityksellisyyden: vaikka tarkastelluilla johtoryhmillä ei ole päätöksentekovaltaa, johtoryhmäkokouksilla voidaan nähdä olevan valtaa. Näin ollen väitän, että on olemassa olosuhteita, joissa ryhmätilanne, kuten kokous, on mielekkäämpi analyysiyksikkö kuin ryhmä itse. Ryhmätutkimuksen on jatkossa tarkasteltava ja teoretisoitava ryhmän ja ryhmätilanteen välistä suhdetta nykyistä enemmän.

Sairaalajohtoryhmätutkimuksen kannalta tutkimukseni tulokset osoittavat organisaatiorakenteiden merkittävyyden vuorovaikutusta ajoittavina tekijöinä, vaikka kokousosallistujat itse kokisivat vuorovaikutuksen avoimeksi ja vapaaksi. Kun vuorovaikutusta rajoittavat rajapinnat siirretään hallinnollisesta ympäristöstä kliiniseen ympäristöön, puhutaan viime kädessä potilasturvallisuudesta: onko eri professioiden ja ekspertiisien välillä todella toimiva yhteys? Sairaalassa vaikuttaa vallitsevan tieto- ja viestintäkäsitys, jonka mukaan tieto on jotain, jota voidaan siirtää lähettäjän ja vastaanottajan välillä. Mikäli kokouksia käytetään tällaisina 
tiedotuskanavina, ja yhteisten merkitysten luomisen tärkeyttä ei tiedosteta, on varsin mahdollista, että organisaation johdon lähettämä viest vääristyy matkalla ylhäältä alaspäin. Kokouksissa voidaan merkityksentää ja konstituoida erilaista sairaalaa kuin johto ylimmän johtoryhmän muistioiden muodossa viestii. Väitän, että koska kokoukset tuottavat organisaatiota vuorovaikutusta rajoittavista rakenteista tietoiseksi tuleminen ja näiden rajojen ylittäminen johtoryhmäkokouksissa vaikuttaa pitkällä ai kajänteellä koko organisaation vuorovaikutukseen.

Kokoustutkimuksen kannalta tutkimukseni tulokset vahvistavat näkemystä kokouste keskeisestä asemasta osana organisaatioiden organisoitumista. Organisaatio voidaan näh dä vuorovaikutustilanteista muodostuvaksi, kompleksiseksi verkostoksi. Näiden vuorovaikutustilanteiden joukossa kokoukset ovat merkittäviä kiintopisteitä, jotka edustavat pysyvyyttä ja joissa luodaan merkityksiä organisaatiolle. Kokoukset ovat organisatorisia rituaaleja, joissa yksilöt asettuvat osaksi organisaatiota ja rationalisoivat organisaation prosesseja rakentaessaan yhteisöllisyyttä. Väitän, että kokoukset ovat organisatorisia, ei-inhimillisiä toimijoita jotka saavat vaikutuksia aikaan sekä kokousosallistujissa että organisaatioissa. Kokous on sääntö vuorovaikutukselle eli se saa ihmiset käyttäytymään tietyllä tavalla: käyttäytymisee vaikuttavat asialista, kokousmuistiot ja kokousten tavoitteet ja joskus nämä ohjaavat ihmiset käyttäytymään näytelmämäisesti, esimerkiksi esittämään, että käsiteltävä asia on uusi, vaikka se todellisuudessa on jo kaikkien tiedossa. Osallistujat myös tuovat kokouksiin asioita, joiden he toivovat vaikuttavan organisaation toimintaan. Kun kokousten toimijuutta tarkastellaan vatsastapuhumisen vertauskuvan kautta, voidaan kokous nähdä vatsastapuhujana ja kokousosallistujat nukkeina silloin, kun kokous laittaa osallistujat puhumaan tietyllä tavalla. Sama toimii toisinpäin: kokousosallistujat ovat vatsastapuhujia ja kokous nukke silloin, kun osallistujat käyttävät kokousta ja siitä laadittavia muistioita esimerkiksi omien tavoitteidensa edistämiseen

Kokoukset ovat paljon enemmän, kuin usein tullaan ajatelleeksi. Ehkä suhtautuminen koouksiin muuttuisi, mikäli ymmärrettäisiin, että kokoukset ovat itsessään arvokkaita ja myös ei-aikaansaava tai näennäisesti tehoton kokouskeskustelu voi olla arvokasta itsessään. Mikäli keskitymme ainoastaan kokousprosessien tehostamiseen, päätöksentekoon ja ideointiin, saatamme kadottaa jotain perin inhimillistä.

Väitöskirja on luettavissa verkossa osoitteessa

http://urn.fi/URN:ISBN:978-951-39-7578-4 